\title{
A role for doctors in assisted dying? An analysis of legal regulations and medical professional positions in six European countries
}

\author{
G Bosshard, ${ }^{1}$ B Broeckaert, ${ }^{2}$ D Clark, ${ }^{3}$ L J Materstvedt, ${ }^{3,5}$ B Gordijn, ${ }^{4}$ H C Müller-Busch ${ }^{6}$
}

- Additional data are published online only at http://jme.bmj. com/vol34/issue1

${ }^{1}$ Institute of Legal Medicine, University of Zurich, Switzerland: ${ }^{2}$ Interdisciplinary Centre for the Study of Religious \& Worldview, Catholic University of Leuven, Belgium; ${ }^{3}$ International Observatory on End of Life Care, Lancaster University, United Kingdom; ${ }^{4}$ Department of Ethics, Philosophy and History of Medicine, Radboud University Nijmegen Medical Centre, The Netherlands; ${ }^{5}$ Department of Philosophy, Norwegian University of Science and Technology, Trondheim, Norway; ${ }^{6}$ Department of Palliative Medicine,

Gemeinschaftskrankenhaus Havelhöhe, University Witten/ Herdecke, Berlin, Germany

Correspondence to:

Dr G Bosshard, Institute of Legal Medicine, Winterthurerstrasse

190 / Bau 52, 8057 Zurich,

Switzerland; bosh@irm.unizh.ch

Received 16 August 2006 Revised 28 November 2006 Accepted 6 December 2006

\section{ABSTRACT}

Objectives: To analyse legislation and medical professional positions concerning the doctor's role in assisted dying in western Europe, and to discuss their implications for doctors.

Method: This paper is based on country-specific reports by experts from European countries where assisted dying is legalised (Belgium, The Netherlands), or openly practiced (Switzerland), or where it is illegal (Germany, Norway, UK).

Results: Laws on assisted dying in The Netherlands and Belgium are restricted to doctors. In principle, assisted suicide (but not euthanasia) is not illegal in either Germany or Switzerland, but a doctor's participation in Germany would violate the code of professional medical conduct and might contravene of a doctor's legal duty to save life. The Assisted Dying for the Terminally III Bill proposed in the UK in 2005 focused on doctors, whereas the Proposal on Assisted Dying of the Norwegian Penal Code Commission minority in 2002 did not.

Professional medical organisations in all these countries except The Netherlands maintain the position that medical assistance in dying conflicts with the basic role of doctors. However, in Belgium and Switzerland, and for a time in the UK, these organisations dropped their opposition to new legislation. Today, they regard the issue as primarily a matter for society and politics. This "neutral" stance differs from the official position of the Royal Dutch Medical Association which has played a key role in developing the Dutch practice of euthanasia as a "medical end-of-life decision" since the 1970s.

Conclusion: A society moving towards an open approach to assisted dying should carefully identify tasks to assign exclusively to medical doctors, and distinguish those possibly better performed by other professions.

There has been extensive debate on assisted suicide and euthanasia in westernised countries during the last twenty years. At the same time, we have seen an increase in the acceptance of assisted suicide and euthanasia (hereafter: "assisted dying" to cover both phenomena) among the general public in most western European countries. ${ }^{1}$ In several of them, corresponding political attempts have been made to change the penal code. ${ }^{2-5}$ Such attempts have succeeded in The Netherlands and Belgium. ${ }^{67}$ An open practice of assisted suicide has developed in Switzerland over the last two decades, based on the non-penalisation of unselfish assistance with suicide that exists under Swiss law. ${ }^{3}$

The medical profession has traditionally maintained a clear distance from euthanasia and assisted suicide. However, since there is active debate in many European countries, and proposed or even enacted legislation in some places, it has become increasingly difficult to justify such distance by simply referring to the law or to common sense arguments against any assistance in dying. It does not make it any easier for doctors that discussions in the media, courts, and legislatures often assume assistance in dying to be exclusively a physician's task. $^{5-7}$ In order to avoid being overtaken by possible political developments, doctors are challenged to either give specific reasons why they should not be involved, or work out the role they could conceivably play if need be.

This paper analyses legislation and, in particular, medical professional positions on the doctor's role in assisted dying in certain Western European countries. It follows their development and discusses the implications for the doctors themselves.

\section{METHOD}

To provide an overview of the possible positions in the field, an approach taking "country" as the entity for comparison was considered appropriate. Not only legal regulations, but also medical ethical positions seem to develop in ways that are highly country-specific. The country is still the most important predictor of doctors' attitudes and practices in the field of end-of-life decisions in Europe. $^{8}$

We included countries where assisted dying has been legalised or is openly practiced (Belgium, The Netherlands, Switzerland), and countries where it remains illegal or otherwise banned from practice (Germany, Norway, the United Kingdom). An expert in the field of assisted dying familiar with both the legal situation and the medical professional position from each country was invited to join the research team. These representatives do not necessarily agree on whether assisted dying should be allowed or on the possible role of doctors.

Each participant was asked the following key questions:

1. Is assisted suicide and/or euthanasia unpunished/legal in your country, or is there any attempt to make it unpunished/legal? What is the (envisaged) role of the doctor in this (proposed) law?

2. What is the official position of the medical profession on assisted dying and on a possible role of doctors in these practices? Has this position changed in any way in recent years?

In this study, the term "assisted dying" includes both euthanasia and assisted suicide; in keeping 
with common usage, "euthanasia" means only voluntary euthanasia. ${ }^{9}$

\section{RESULTS}

\section{Legal situation with regard to assisted dying (table 1)}

Although euthanasia and assisted suicide were illegal in The Netherlands until recently (articles 293 and 294 of the Dutch penal code), both practices were tolerated by the courts from the early 1970s. The Netherlands eventually became the first country in Europe to formally depenalise assisted dying by a law (Review Procedure Act) that came into force in April 2002. ${ }^{6}$ Belgium, where no relevant case law and no established or regulated euthanasia practice similar to that of The Netherlands existed, followed suit in September 2002, after having enacted a euthanasia law in May the same year.'

In Switzerland, assisted suicide (but not euthanasia) is not illegal according to the 1918 penal code, provided assistance is given without any motives of self-interest. ${ }^{3}$ The legal situation is similar in Germany where assisted suicide (but not euthanasia) is not illegal in principle. ${ }^{2}$ However, unlike in Switzerland, in Germany assisted suicide may legally conflict with a doctor's or a relative's obligation to save life. Both euthanasia and assisted suicide are prohibited under the Norwegian Penal Code (articles 235 and 236) dating back to 1902. ${ }^{4}$ The same holds true for the UK where even suicide was a crime in England and Wales until 1961. ${ }^{5}$ The Suicide Act then decriminalised suicide but retained the criminal prohibition of aiding and abetting.

\section{Group targeted as assistants in dying by legislation or proposed bills (table 2)}

Both the Dutch Review Procedures Act and the Belgian Euthanasia Law are restricted to doctors by exempting these professionals from penal liability for assistance in dying, provided certain criteria of due care are met. ${ }^{6}$

The non-penalisation of assisted suicide in the German and Swiss Penal Codes differs in that it applies to everyone, be they doctors or not. In 2001, the Swiss Federal Parliament confirmed both the current legal situation and the activities of Swiss rightto-die societies, in which both doctors and non-physicians

Table 1 Assisted suicide and euthanasia in six European countries current legal situation (bold), and developments since 2000

\begin{tabular}{|c|c|c|}
\hline & $\begin{array}{l}\text { Allowance of assisted } \\
\text { suicide (AS) and/or } \\
\text { euthanasia (E) }\end{array}$ & Statutory regulation \\
\hline Belgium & $n o \rightarrow$ yes $(E)$ & $\begin{array}{l}\text { Separate Act Concerning Euthanasia } \\
\text { (Criminal Code remains unchanged)* }\end{array}$ \\
\hline \multirow[t]{2}{*}{ Germany } & (yes AS) & $\begin{array}{l}\text { (No specific regulation in German Penal } \\
\text { Code) } \dagger\end{array}$ \\
\hline & no (E) & (Art. 216 German Penal Code) \\
\hline The Netherlands & $(n o) \neq \rightarrow$ yes & $\begin{array}{l}\text { Amendment of the Dutch Criminal Code Art. } \\
293 \text { (killing on request) and Art. } 294 \\
\text { (assisted suicide) }\end{array}$ \\
\hline Norway & no & Art. 235 and Art. 236 Norwegian Penal Code \\
\hline \multirow[t]{2}{*}{ Switzerland } & yes (AS) & (Art. 115 Swiss Penal Code)§ \\
\hline & no (E) & (Art. 114 Swiss Penal Code) \\
\hline United Kingdom & no & $\begin{array}{l}\text { Section } 2 \text { Suicide Act for England and Wales } \\
1961\end{array}$ \\
\hline
\end{tabular}

Unless specified, all statements refer to both assisted suicide and euthanasia. Italics: developments since 2000

* The legal status of assisted suicide in Belgium is unclear.

† Physician-assisted suicide may legally conflict with a doctor's obligation to save life \$ Although illegal until 2002, both assisted suicide and euthanasia were tolerated in The Netherlands from the early 1970s.

$\S$ Assisting in suicide is not illegal as long as there are no motives of self-interest. participate in suicide assistance. ${ }^{3}$ In Germany, a group of legal experts recently proposed that doctors assisting patients in suicide should not be censured or prosecuted, which in fact would mean that the legal situation with respect to assisted suicide would become similar to that in Switzerland, both in general and for doctors in particular. ${ }^{2}$

The most important attempt in the UK to change the legal situation, the Assisted Dying for the Terminally Ill Bill proposed in the UK in 2005 and rejected by the House of Lords in 2006, focused on doctors. ${ }^{5}{ }^{10}$ In contrast, the 2002 minority Proposal on Assisted Dying of the Norwegian Penal Code Commission turned down by the Norwegian Parliament in an unanimous vote in May 2005 - made no specific mention of doctors but proposed a requirement that the patient be "terminally ill". ${ }^{4}$

\section{Medical professional positions (table 3)}

The Royal Dutch Medical Association played a key role in developing the Dutch euthanasia model from the very beginning, without expressing any major concerns as to the compatibility of this practice with medical professional ethics. ${ }^{11}$ Allowing a role for non-doctors was hardly ever seriously considered. An inquiry commissioned by the Royal Dutch Medical Association recently concluded that individuals with no illness at all could also qualify for assistance in dying, and that even in these cases doctors should be the only ones to decide whether the "suffering through living" is great enough. ${ }^{12}$

In contrast, the Belgian National Council of Physicians found it difficult to establish an adequate position when confronted with the rapid and radical legal changes in the field of euthanasia in Belgium in the early 2000s. The reality of the new Belgian law was finally accepted in an Advice of March 2003. ${ }^{13}$ Art. 95 of the Code of Medical Deontology, which previously prohibited doctors from providing any assistance in dying, was changed only in March 2006. ${ }^{14}$ In the revised Art. 9598, the Code now mentions the duty of the physician, on receiving a question regarding the end of life, to inform the patient of the initiatives that the latter can take (including writing a living will covering euthanasia) and includes a somewhat ambiguous statement that a doctor should provide any medical and moral assistance required.

The Swiss Academy of Medical Sciences took a different route towards adopting a "neutral" stance. The Academy maintains the basic incompatibility of assisted dying with the role of the doctor, but today respects assistance in suicide as the doctor's personal decision in the individual case. ${ }^{15}$

Medical associations in Germany, Norway and the UK continue to strongly condemn assisted dying in any form. ${ }^{516} 17$ In the UK however, the fact that both the British Medical Association and the Royal College of Physicians of London for a time adopted a neutral position to the Assisted Dying for the Terminally Ill Bill, but later backtracked and again took a stance against legislation, shows how controversial the subject is, even amongst doctors in this country. ${ }^{18} 19$

More details on the legislation and medical professional positions and their development in the various countries, including additional references, can be found online..

\section{DISCUSSION}

\section{Doctors between resistance and acquiescence}

Faced with increasing public acceptance of assisted dying in Europe, corresponding attempts to change the penal code, and actual changes of the law in some countries, the medical profession mostly strives to prevent or to slow down the 
Table 2 Assisted suicide and euthanasia in six European countries: target group (bold) of legislation or proposed bills

\begin{tabular}{|c|c|c|}
\hline & $\begin{array}{l}\text { Target group of } \\
\text { (proposed) } \\
\text { legislation }\end{array}$ & $\begin{array}{l}\text { According to statutory regulation or } \\
\text { proposed legislation }\end{array}$ \\
\hline Belgium & doctors only & $\begin{array}{l}\text { Act Concerning Euthanasia, May 2002: } \\
\text { Conditional decriminalisation of euthanasia } \\
\text { performed by a physician* }\end{array}$ \\
\hline Germany & not specified & $\begin{array}{l}\text { Non-penalty of assisted suicide holds for } \\
\text { everyone } \dagger\end{array}$ \\
\hline The Netherlands & doctors only & $\begin{array}{l}\text { Review Procedure Act, April 2002: exemption } \\
\text { for doctors from penalty of assisted suicide and } \\
\text { killing on request }\end{array}$ \\
\hline Norway & not specified & $\begin{array}{l}\text { Penal Code Commission, minority proposal, no } \\
\text { mention of doctors; rejected in May } 2005 \text { by the } \\
\text { Norwegian Parliament }\end{array}$ \\
\hline Switzerland & not specified & $\begin{array}{l}\text { Non-penalty of assisted suicide without motives } \\
\text { of self-interest holds for everyone }\end{array}$ \\
\hline United Kingdom & doctors only & $\begin{array}{l}\text { Assisted Dying for the Terminally III Bill targeted } \\
\text { at doctors only; rejected in May } 2006 \text { by the } \\
\text { House of Lords }\end{array}$ \\
\hline \multicolumn{3}{|c|}{$\begin{array}{l}\text { Unless specified, all statements refer to both assisted suicide and euthanasia. Italics: } \\
\text { bill/proposal } \\
\text { * The legal status of (physician-) assisted suicide - not regulated by the euthanasia } \\
\text { law - is unclear. } \\
\text { † Physician-assisted suicide may legally conflict with a doctor's obligation to save life } \\
\text { ("Garantenpflicht"). Current legal developments aim at exempting doctors from a } \\
\text { particular "Garantenpflicht". }\end{array}$} \\
\hline
\end{tabular}

process. What is occurring may be described as a power struggle: society wants the option of physician-assisted death to be available, while the overwhelming majority of medical organisations continue to view such assistance as incompatible with their codes of professional ethics. Even so, there is no unanimity within the medical profession. ${ }^{20}$ Those specialists who are most likely to be entrusted with assisting in death (eg oncologists, palliative care doctors) are those who oppose the legalisation of assisted dying most strongly. In other words, the conflict is essentially between those who want the option of assisted dying to be available, and those who would be responsible for implementing it. ${ }^{21} 22$

So far, doctors have been able to prevent any opening up in Germany, Norway, and the UK. Nevertheless, the campaign debate for the Assisted Dying for the Terminally Ill Bill in the UK was powerful enough to cause the British Medical Association and the Royal College of Physicians of London to waive their opposition for a while. ${ }^{18} 19$ And at the moment there is considerable pressure on the German Medical Association arising from the proposal of a group of legal experts that doctors assisting patients in suicide should neither be prosecuted under criminal law nor censured by medical professional ethics. ${ }^{2}$

In the last few years, Swiss and Belgian doctors gradually acquiesced in what had already been legally condoned or established as a new legislation in a democratic process, respectively. The process of acquiescence is particularly impressive in Belgium, where legal changes made in direct opposition to the official medical ethical position presented the medical profession with a fait accompli. The Belgian National Council could do nothing more than state: "When in a democratic state a law [on ethical issues] is established and this law respects the freedom of conscience of each physician, the existence of this law cannot be ignored by a public institution such as the Order of Physicians." "13 In Switzerland, too, the Swiss Academy of Medical Sciences was forced to moderate its statement that "assistance in suicide is not a part of a doctor's activity" so that assistance in suicide in individual cases now has to be respected as the doctor's personal decision. ${ }^{14}$
Table 3 Assisted suicide and euthanasia in six European countries current official medical professional positions (bold), and developments since 2000

\begin{tabular}{|c|c|c|}
\hline & $\begin{array}{l}\text { Allowance of doctors' } \\
\text { involvement }\end{array}$ & According to \\
\hline Belgium & no $\rightarrow$ neutral $^{*}$ & $\begin{array}{l}\text { Code of Medical Deontology of the Belgian } \\
\text { National Council of Physicians, position } \\
\text { modified in March } 2006\end{array}$ \\
\hline Germany & no & $\begin{array}{l}\text { Principles of the German Medical } \\
\text { Association, position maintained in May } \\
2004\end{array}$ \\
\hline $\begin{array}{l}\text { The } \\
\text { Netherlands }\end{array}$ & yes & $\begin{array}{l}\text { Guidelines of the Royal Dutch Medical } \\
\text { Association, position maintained in April } \\
2002\end{array}$ \\
\hline Norway & no & $\begin{array}{l}\text { Ethical Rules of the Norwegian Medical } \\
\text { Association, position maintained in June } \\
2002\end{array}$ \\
\hline Switzerland & $\begin{array}{l}\text { no } \rightarrow \text { neutral }(A S) \\
\text { no }(E)\end{array}$ & $\begin{array}{l}\text { Medical-ethical Guidelines of the Swiss } \\
\text { Academy of Medical Sciences, position } \\
\text { modified in December } 2004\end{array}$ \\
\hline $\begin{array}{l}\text { United } \\
\text { Kingdom }\end{array}$ & no $\leftrightarrow$ neutral & $\begin{array}{l}\text { Official view of the British Medical } \\
\text { Association, June } 2000 \text { (confirmed by a } \\
\text { BMA representative vote, July 2006) } \dagger\end{array}$ \\
\hline
\end{tabular}

Unless specified, all statements refer to both assisted suicide and euthanasia Italics: developments since 2000

* Concerns both euthanasia and assisted suicide as long as requirements of the euthanasia law (including presence of a physician) are met.

$\uparrow$ Abolishing an earlier BMA representatives' vote in July 2005 in favour of a neutral stance

Only in The Netherlands do we find almost complete symmetry between what the law conceives as the medical profession's role in assisted dying and the official view of the profession itself. However, evidence from The Netherlands suggests a continuing unwillingness of doctors to report cases of such assistance to the authorities, and a return to practices such as terminal sedation that are accepted as normal medical practice and do not need to be reported to the authorities. ${ }^{23}$

\section{Keeping out or being the experts?}

Open regulation of assisted dying brings doctors into a basic conflict. On the one hand, many doctors do not wish to have anything to do with a practice that they regard as incompatible with professional ethics. On the other hand, once opening up seems inevitable, they want to introduce the safeguards they deem necessary. The more they get involved in these discussions, however, the more they are drawn, albeit unwillingly, into the role of experts in a field that extends far beyond medicine. Utilisation of that exclusive expertise is exactly what is presupposed in much legislation and proposed bills. ${ }^{5-7}$

Should this role be taken on without modification by the medical profession, it would lead in the direction of the Dutch model where euthanasia and assisted suicide have been socialised within the medical profession as just another "medical end-of-life decision". ${ }^{24}$ However, such a role for the medical profession seems particularly inappropriate if, as has happened in The Netherlands, the indications for assisted dying are progressively extended. ${ }^{12}$ Requests to die in cases of "suffering through living" can be seen either as a strictly personal matter or as a social issue, that is, something that society has a duty to deal with. But as these individuals do not suffer from any medical condition at all, or at least not from any severe illness, it is difficult to justify the view that their plight is a medical matter. There is hardly any argument why doctors should have more expertise in such cases than other professionals.

However, it has been suggested that open regulation of assisted dying could also be implemented by establishing a 
suicide service outside clinical care, run by a designated interdisciplinary team. ${ }^{25}$ This model, in which non-penalisation of assistance in dying would be restricted to these specialised services rather than to any one profession, could ensure competent assessment of the person wanting to die according to standard regulations agreed on by the public through a political process. Any role conflict for clinicians faced with a patient's request for assistance in dying would thereby be avoided, as their role would be clearly confined to openly discussing the situation, indicating possible treatment or palliative care options, and offering further support in this respect. Nevertheless, no state has yet shown great interest in engaging in a field in which it is extremely difficult to establish appropriate decision criteria but, at the same time, any wrong decision has far-reaching and irreversible consequences.

\section{An interdisciplinary approach?}

Against the background of our analysis, it is apparent that, if society is willing to make assisted death an available option, the responsibility for such decisions must be spread as widely as possible, that is, borne by society as a whole. ${ }^{25}$ It is not enough that the law and ethical guidelines lay down limits for doctors who assist in dying and that the observance of these conditions is monitored by lawyers and - as is the case in The Netherlands - ethicists. Much rather, these two groups, together with other professionals such as clergy, nurses, pharmacists, social workers, and any "lay people" who have sufficient experience of life, should be prepared to bear joint responsibility for specific cases, for example when a particularly difficult decision has to be taken. Whether or not a state-run service for assisted dying, as outlined above, ${ }^{25}$ is the most appropriate instrument is another question altogether, as this might be too bureaucratic and impersonal to meet the expectations and needs of the individuals wanting to die and their families.

What doctors can do at this stage is to identify where medical expertise is essential in this field and to define those questions to which medical knowledge provides no answer. Given the fact that most professional medical organisations decline even to consider the subject at the present time, official positions of doctors in this field are scarce. However, a Consensus Panel of the University of Pennsylvania Center for Bioethics, Pennsylvania, USA, succeeded in bringing together a number of acknowledged experts in this field. ${ }^{26}$ The panel identified communication of information about diagnosis, prognosis, and the full range of treatment options as clearly within the doctor's expertise. Concomitant factors such as depression would, of necessity, have to be assessed by a doctor. According to the panel, tasks such as addressing questions of coercion, spiritual issues, and even symptom control, are often better performed by nurses, social workers, and clergy or other spiritual advisors. These experts also raised the question whether it would be better to assign a non-physician to coordinate and supervise the overall process.

Interestingly, these suggestions, although developed independently in a different cultural and health-care context, correspond closely with the position of the Swiss Academy of Medical Sciences on assisted suicide, as outlined in their medical-ethical guidelines on the care of patients at the end of life. ${ }^{15}$ According to the Swiss Academy of Medical Sciences, exclusively medical tasks are to establish that the patient is approaching the end of life, to discuss the medical condition and its consequences and, if desired, to implement alternative options for treatment and palliative care. On the other hand, ascertaining that the patient is capable of making the decision and that the wish to end life is well-considered, persistent, and arrived at without external pressure is not exclusively a medical task - for this reason, the person providing a second opinion on these points must not necessarily be a doctor.

\section{CONCLUSIONS}

Against the background of increasing public acceptance of assisted dying in Europe, the fundamental question of the appropriate role for doctors in an area that goes beyond medicine remains contentious. A society striving for an open approach towards assisted dying should carefully identify the tasks that should be assigned exclusively to medical doctors and separate out those that might be better performed by other professions.

Acknowledgements: $G B$ and $B G$ thank the teams of both the Centre for the Economic and Social Aspects of Genomics (GESAGen) and of the International Observatory on End of Life Care (IOELC) at Lancaster University for their outstanding hospitality and friendship.

All authors are indebted to Dr Mergl Clarke for translating parts of the text into English and for critically revising the whole manuscript.

Competing interests: None.

\section{REFERENCES}

1. Cohen J, Marcoux I, Bilsen J, et al. Trends in acceptance of euthanasia among the general public in 12 European countries (1981-1999). Eur J Public Health 2006;16:663-9.

2. Schöch H, Verrel T. Alternativ-Entwurf Sterbebegleitung [Alternative blueprint on end-oflife care in Germany]. Goltdammer's Archiv für Strafrecht (GA) 2005;152:553-624.

3. Bosshard G, Fischer S, Bär W. Open regulation and practice in assisted dying. How Switzerland compares with the Netherlands and Oregon. Swiss Med Wkly 2002;132:527-34.

4. Norges offentlige utredninger - NOU 2002: 4. Ny straffelov. Straffelovkommisjonens delutredning VII [New penal code. The penal code commission's review, part VII], March 2002. http://www.regjeringen.no/nb/dep/jd/dok/Nover/2002/Nov-200204.html?id = 380296 (accessed 6 November 2007)

5. House of Lords. Assisted Dying for the Terminally III Bill Committee. Assisted Dying for the Terminally III Bill - First Report (April 2005).http://www.publications. parliament.uk/pa/ld/ldasdy.htm (accessed 26 October 2007)

6. Wet toetsing levensbeëindiging op verzoek en hulp bij zelfdoding [Termination of Life on Request and Assisted Suicide Law (Review Procedures) Act 2002]. Staatsblad van het Koninkrijk der Nederlanden 2001;194. http://www.minbuza.nl/binaries/en-pdf/ pdf/euth-amendedbill-en.pdf (accessed 26 October 2007)

7. Euthanasia (Belgium) Bill. Bull Med Eth 2002; January:9-11.

8. Rebagliato M, Cuttini M, Broggin L, et al. Neonatal end-of-life decision making. Physicians' attitudes and relationship with self-reported practices in 10 European countries. JAMA 2000;284:2451-9.

9. Materstvedt LJ, Clark D, Ellershaw J, et al. Euthanasia and physician-assisted suicide: a view from an EAPC Ethics Task Force. Palliative Medicine 2003;17:97-101.

10. Dyer C. UK House of Lords rejects physician assisted suicide. BMJ 2006;332:1169

11. KNMG, Standpunt Federatiebestuur KNMG inzake euthanasia [The federal board's position on Euthanasia], 2002. http://knmg.artsennet.nl/vademecum/files/VI.07.html (accessed 26 October 2007)

12. Sheldon T. Dutch euthanasia law should apply to patients "suffering through living", report says. BMJ 2005:330:61.

13. Nationale Raad van de Orde der Geneesheren, Advies betreffende palliatieve zorg, euthanasie en andere medische beslissingen omtrent het levenseinde [The Nationa Council of the Order of Physicians, advice on palliative care, euthanasia and other medical end-of-life decisions], March 2003. http://195.234.184.64/web-Ned/nl/a100/ a100006n.htm (Dutch) or http://195.234.184.64/web-Fr/fr/a100/a100006f.htm (French) (accessed 26 October 2007)

14. Code van geneeskundige plichtenleer opgesteld door de Nationale Raad van de Order der Geneesheren [Code of Medical Deontology of the National Council of the Order of Physicians], March 2006. http://195.234.184.64/web-Ned/deonton.htm (Dutch) or http://195.234.184.64/web-Fr/deont_f.htm (French) (accessed 26 October 2007)

15. Schweizerische Akademie der Medizinischen Wissenschaften. Betreuung von Patienten am Lebensende. Medizinisch-ethische Richtlinien [Care of patients at the end of life, medical-ethical guidelines]. Schweiz Ärztezeitung 2005;86:172-6.

16. Bundesärztekammer. Grundsätze der Bundesärztekammer zur ärztlichen Sterbebegleitung [Principles of the German Medical Association on medical end-oflife care]. Deutsches Ärzteblatt 2004;101:1298-1299.

17. The Norwegian Medical Association. Etiske regler for leger [Ethical rules for doctors], 1961 - last amended June 2002; section on assisted dying amended October 1994. http://www.legeforeningen.no/index.gan?id = 485 (accessed 26 October 2007)

18. Royal College of Physicians of London. Written evidence to the House of Lords Select Committee on the Assisted Dying for the Terminally III Bill (September 2004). 
http://www.rcplondon.ac.uk/news/statements/statements_assisted_dying.htm (accessed 6 November 2007)

19. Kmietowicz Z. Doctors backtrack on assisted suicide. BMJ 2006;333:64.

20. Emanuel EJ. Euthanasia and physician-assisted suicide. A review of the empirical data from the United States. Arch Int Med 2002;162:142-52.

21. Müller-Busch HC, Oduncu FS, Woskanjan S, et al. Attitudes on euthanasia, physician-assisted suicide and terminal sedation - a survey of the German Association for Palliative Medicine. Med Health Care Philos 2004;7:333-9.

22. Vollmann J, Hermann E. Einstellungen von Psychiatern zur ärztlichen Beihilfe zum Suizid [Attitudes of psychiatrists toward physician-assisted suicide]. Fortschr Neurol Psychiatr 2002;70:601-8.
23. Gordijn B, Janssens R. Euthanasia and Palliative Care in the Netherlands: An Analysis of the Latest Developments. Health Care Analysis 2004;12:195-207

24. Onwuteaka-Philipsen BD, van der Heide A, Koper D, et al. Euthanasia and other end-of-life decisions in the Netherlands in 1990, 1995, and 2001. Lancet 2003;362:395-9.

25. Finlay IG, Wheatley VJ, Izdebski C. The House of Lords Select Committee on the Assisted Dying for the Terminally III Bill: implications for specialist palliative care. Palliat Med 2005;19:444-53.

26. Faber-Langendoen K, Karlawish JHT. Should assisted suicide be only physician assisted? Ann Intern Med 2000;132:482-7.

\section{BMJ Clinical Evidence-Call for contributors}

BMJ Clinical Evidence is a continuously updated evidence-based journal available worldwide on the internet which publishes commissioned systematic reviews. BMJ Clinical Evidence needs to recruit new contributors. Contributors are healthcare professionals or epidemiologists with experience in evidencebased medicine, with the ability to write in a concise and structured way and relevant clinical expertise.

Areas for which we are currently seeking contributors:

- Secondary prevention of ischaemic cardiac events

- Acute myocardial infarction

- MRSA (treatment)

- Bacterial conjunctivitis

However, we are always looking for contributors, so do not let this list discourage you.

Being a contributor involves:

- Selecting from a validated, screened search (performed by in-house Information Specialists) valid studies for inclusion.

- Documenting your decisions about which studies to include on an inclusion and exclusion form, which we will publish.

- Writing the text to a highly structured template (about 1500-3000 words), using evidence from the final studies chosen, within 8-10 weeks of receiving the literature search.

- Working with BMJ Clinical Evidence editors to ensure that the final text meets quality and style standards.

- Updating the text every 12 months using any new, sound evidence that becomes available. The BMJ Clinical Evidence in-house team will conduct the searches for contributors; your task is to filter out high quality studies and incorporate them into the existing text.

- To expand the review to include a new question about once every 12 months.

In return, contributors will see their work published in a highly-rewarded peer-reviewed international medical journal. They also receive a small honorarium for their efforts.

If you would like to become a contributor for BMJ Clinical Evidence or require more information about what this involves please send your contact details and a copy of your CV, clearly stating the clinical area you are interested in, to CECommissioning@bmjgroup.com.

\section{Call for peer reviewers}

BMJ Clinical Evidence also needs to recruit new peer reviewers specifically with an interest in the clinical areas stated above, and also others related to general practice. Peer reviewers are healthcare professionals or epidemiologists with experience in evidence-based medicine. As a peer reviewer you would be asked for your views on the clinical relevance, validity and accessibility of specific reviews within the journal, and their usefulness to the intended audience (international generalists and healthcare professionals, possibly with limited statistical knowledge).

Reviews are usually 1500-3000 words in length and we would ask you to review between 2-5 systematic reviews per year. The peer review process takes place throughout the year, and our turnaround time for each review is 10-14 days. In return peer reviewers receive free access to BMJ Clinical Evidence for 3 months for each review.

If you are interested in becoming a peer reviewer for BMJ Clinical Evidence, please complete the peer review questionnaire at www.clinicalevidence.com/ceweb/contribute/peerreviewer.jsp 